\title{
THE NEW YORK NEGRO'S BATTLE FOR POLITICAL RIGHTS, I777-I865
}

The American revolution, with its accompanying changes in the economic, social and political life of the thirteen colonies, failed to alter the Negroes' "outsider status". In this article the struggle for political rights will be considered as a factor in changing that "outsider status." It seems justifiable to single out for special treatment a period of less known political action aimed at improving - or sometimes simply defending - the Negro's status as a citizen.

In order to prevent an improvement of the Negro's socio-economic status, one had, moreover, to include restrictions on his political and civil rights. This was necessary to assure the white man of a consistent approach to his concept of Negro, and to keep the circle perfect. Thus the American Revolution fought, partly, to equalize political representation, failed to change pre-revolutionary public attitudes toward the Negro's political and civil rights. Although the free Negro was known as "free", in none of the New England States was he free as the white man. However, he was part of the community. Some Negroes did exercise political rights, but always in a restricted manner; in the northern states special property qualifications demarcated Negroes' suffrage from that of the whites. ${ }^{1}$ It should be noted that there was not a single northern slave holding state that permitted unlimited manumission; nor one that permitted Negroes to testify in litigation. These rules were rigidly enforced after the Revolution. ${ }^{2}$

The Negroes' reaction to unequal suffrage was one of aggressiveness from the American Revolution through the Civil War. This aggressive Negro attitude is contrary to the commonly held belief that Negroes

${ }^{1}$ C. Wesley, "Negro Suffrage in the Period of the Constitution's Making $1787^{-1865}$ ", in: Journal of Negro History, April 1947, pp. I48-1 49.

2 T. R. R. Cobb, An Inquiry into the Law of Negro Slavery in the United States of America (Philadelphia, Pa., 1858), pp. 287, 290. 
are apathetic toward their political and civil status in American society. ${ }^{1}$

This article will stress the aggressive attitude displayed by Negroes and their friends in their struggle to make democracy work during the period I777-I 865 .

\section{SUFFRAGE UNDER NEW YORK STATE'S I 777 CONSTITUTION TO I 826}

New York State's first constitution, adopted on April 20, 1777, ${ }^{2}$ specifically omitted any reference to race, creed, or previous condition of servitude as a bar to suffrage. However, it did state that the right to vote at elections for the State Assembly was granted to "every male inhabitant of full age", who met the residence and property requirements. These were: I) the ownership of a twenty-pound freehold, or 2) the leasing of a tenement at forty shillings. ${ }^{3}$ Different, however, were the voting requirements for State Senator; here the property requirement was one hundred pounds. ${ }^{4}$

Most New Yorkers were opposed to the continuation of Negro suffrage by 1785 . A bill was introduced in that year entitled, "An Act for the Gradual Abolition of Slavery Within This State"; this bill received a two-thirds senate vote and a majority of the assembly. The title is misleading since the contents of the bill actually favored curtailment of Negro suffrage. In this instance, the blackman's suffrage was preserved because of the Council of Revision's veto. ${ }^{5}$

In 1799, an act passed while the Federalists were in power revealed a liberal attitude in existence toward Negroes. This act did provide for the gradual abolition of slavery - the freeing of males at age $\mathbf{2 8}$ and females at age 25. The close association of many free Negroes with their Federalists employers, and passage of the 1799 Act gave rise to the allegation that Negroes were under the domination of the Federalists. We do not know whether the alignment of Negroes with the Federalists was coincidental; but we do know that the Federalists won the election of 1800 by the vote of a single Negro ward. ${ }^{6}$ The opposing political party, the Democratic-Republicans, accepted this

1 The New York Times, June 19, I960.

${ }^{2} \mathrm{~J}$. S. Murphy, Interesting Documents (Containing the Constitution of New York State with its amendments), New York, I8 19.

${ }^{3}$ C. Z. Lincoln, The Constitutional History of the State of New York (Rochester, N.Y, Igo6), Vol. I., pp. r 10- 17 I.

4 Ibid., g. I72; M. W. Ovington, Half a Man (N.Y,, Igr I), P. I .

${ }^{5}$ E. Olbrich, The Development of Sentiment on Negro Suffrage to I860 (Madison, Wisconsin, 1912), pp. 16, 17, 29.

D. R. Fox, "The Negro in Old New York", in: Political Science Quarterly, June I9I7, p. 256 . 
allegation and sought to mitigate Negroes as a political force. ${ }^{1}$ The Democratic-Republicans opposition gained momentum and they were able to restrict black suffrage. Thus in I 809 polling inspectors of the Democratic-Republican Party began to assume that all Negroes were born in slavery and they refused to permit Negroes to take the prescribed oath that they were born free." A special act "to prevent frauds and for other purposes", was passed by the State Legislature in $181 \mathrm{r}$. It dealt specifically with Negroes and stated that: "whenever any person of color, or black person shall present himself to vote at any election of this state, he shall produce to the inspectors, or persons conducting such an election a certificate of freedom under the hand and seal of one of the clerks of the counties of this state, or under the hand of a clerk of any town within this state [New York]."3

To obtain such a certificate, a Negro or person of color had to appear before one of the Judges of the Supreme Court, where the proof of freedom could be obtained in writing. The cost of this certificate would involve the services of a lawyer, plus twenty-five cents to the Court, a shilling to the County Clerk for filing the certificate in his office. Finally, the man of color had to take an oath that he was the person whose name was listed on the certificate. ${ }^{4}$

Again the Council came to the defense of Negroes since on April s, I8I I, the Council's objections were sufficient to override the act. Chancellor Lansing gave the following reasons for rejection: given the fact that according to the act "persons of color" must produce certificates of freedom at all elections; he found "that the description of 'persons of color' was too indefinite and might be made to include all gradations and/or mixtures between the African and the white man... [furthermore] the act established the principle that all blackmen and men of color are presumed to be slaves until they prove that they are free."5 However, the opponents of Negro suffrage were to have their victory three years later.

In $181_{3}$, it is alleged that the votes of some 300 free Negroes in New York City again decided the election and swept the Federalists into power and determined the character of the State Legislature. ${ }^{6}$ Some delegates at the 182 I Convention contended that this Negro vote in favor of the Federalists was responsible for passage of a new

1 The New York Spectator, April 29, 1809.

2 Ibid.; J. D. Hammond, Political History of the State of New York (Albany, N.Y., I8I1), pp. 143, 164, 351, 360.

3 Journal of the Senate of the State of New York (Albany, I8I I), p. I43.

4 Ibid., p. 360.

5 Olbrich, op. cit., pp. 29-30.

- Reports and Proceedings of the Convention of I82I, p. 212. 
law in $1814 .{ }^{1}$ The 1814 law, limited to New York City, was very similar to the ill-fated I $8 \mathrm{I}$ I law since both required a certificate of freedom to be recorded in the office of the registrar and that a copy of the record had to be presented at each election before a free Negro could vote. The effectiveness of the new law can be gauged by the number of Negroes who actually voted in the spring election of $182 \mathrm{I}-$ 163 as compared to the 300 eight years before in the $18 \mathrm{I}_{3}$ election. ${ }^{2}$ The effectiveness is heightened when we note the Negro population in 1810 and 1820 . In $1810^{3}$ there were some 9,823 Negroes in the city of whom some $1,686^{4}$ were slaves as compared with ro,886 Negroes in $1820^{5}$ of whom some $518^{6}$ were slaves. In other words there was an increase of free Negroes between 1810 and 1820 by some 2,000; yet the number voting was almost 50 percent less in 1820 . Again in $1815^{7}$ new amendments to the law were made with one exception. The latter applied to New York City and New York County, where the law took effect a year earlier. The law stated that free Negroes in New York City were exempted from the law if they had obtained certificates prior to passage of the I8 is act. However, persons of color affected had to register five days prior to an election and they had to deliver their affidavits to the Mayor for inspection. Opponents to Negro suffrage finally achieved their goal. ${ }^{8}$

Negroes, firm believers in revival of causes, felt that success was within their grasp when on March I 3, I 821 , the New York Legislature passed an act to revise the State Constitution. To insure the success of their cause, a Colored People's Convention was held in New York City and a "Memorial" was drafted and sent to the State Legislature. Basically, the plea requested the legislators to forbid passage of any laws that would interfere with the Negroes' political and civil rights. Anti-Negro sentiment, however, was strong enough to pigeonhole the "Memorial". 9 One Republican delegate summed up the political resentment toward Negroes when he stated: "that the political character of the national government was changed [in the 1800 election] by the vote of a single Negro ward in the City of New York."10 To curb

${ }^{1}$ Laws of New York State, 37th Session, pp. 94, 95.

2 Report of the Proceedings and Debates of the Convention of 1821 , pp. 197, 198, 199.

${ }^{3}$ Negro Population, 1790-I9 I 5, pp. 45, 51, 55.

${ }^{4}$ Census of the State of New York for I855, pp. VIII, XI.

5 Negro Population, op. cit.

${ }^{8}$ Census of the State of New York for I 855, op. cit.

7 Journal of the Assembly of the State of New York (Albany, 1815), p. 475.

8 'The New York Spectator, April i9, 18 Is.

A Report of the Debates and Proceedings of the Convention of the State of New York (Albany, i821), p. 185 .

${ }^{10}$ Fox, op. cit., p. 256 . 
Federalist power meant the restriction of Negro suffrage. One of the new restrictive provisions in the new constitution was that Negroes, in order to be eligible to vote, had to own two hundred and fifty dollars worth of real property. ${ }^{1}$

Some sixty persons of color did own the requisite amount of real property, but there were only sixteen who actually voted. These sixteen voters represented some I 2,575 colored residents in the City of New York in $1825 .^{2}$

In 1826 when all property qualifications for whites were abolished, Negroes were still subject to special property requirements. Also, in I 826, the residence requirement for whites was reduced to one year, but Negroes had to meet a three-year residence requirement in addition to the property requirement in order to vote. ${ }^{3}$

In addition to petitioning state legislatures, some Negroes sought other avenues of redress. One of these was the proverbial back to Africa movement. The American Colonization Society did succeed in December $182 \mathrm{x}$ in purchasing the Montserado Territory, in West Africa. A group of American Negroes did settle on Cape Montserado in 1822 with J. Ashmun as one of their leaders. The colony was plagued with fever and barely managed to survive the first few years. In addition to fever they were attacked by surrounding tribes but managed to come to terms with them in time. ${ }^{4}$ Later this was to form the state of Liberia with its capital known as Monrovia, named after President Monroe. Most American Negroes refused to join or leave the United States for Africa. But over and over again we read that members of the Colonization Society "know little of the colored population of this city [New York], except that segment that has come into contact with the law."5

\section{THE NEGRO MOBILIZES HIS FORCES I 827 -I 840}

Legal abolition of slavery in I 827 saw the Negro in New York both mobilize his own forces and secure the cooperation of some whites. This period revealed the emergence of Negro leaders in a divided

1 A Report of the Debates... (Albany, I821), p. I85.

2 Journal of the New York State Assembly (Albany, 1826), reproduced in: The Colored American, March 25, I837.

${ }^{3}$ C. W. Johnson, Black Manhattan (N.Y., r930), p. 27; C. H. Wesley, “The Negroes in the Emancipation Movement”, in: Journal of Negro History, January, I939, p. 91.

4 J. Ashmun, History of the American Colony in Liberia (December I $821-1823$ ) (Washington City, 1826 ), pp. 4-7.

${ }^{5}$ Resolutions of the People of Color at a Meeting Held on the 25 th of January, I831, With an Address to the Citizens of New York in Answer to Those of the New York Colonization Society (N.Y., I83I), pp. I-8. 
Negro world. Despite the dissention within Negro ranks, an organized Negro convention movement did arise. ${ }^{1}$

The Phoenix Society of New York, in $1833,{ }^{2}$ was the first organization completely devoted to the task of equalizing the Negroes' political and civil rights with that of whites. In I 834, the Fourth Annual Convention for the Improvement of the Free Colored People in the City of New York, ${ }^{3}$ a well established organization, appointed a special committee to study the laws of the State of New York with special reference to inequities based on color. The special committee's findings were incorporated in a series of proposals and sent to the state legislature for action. In essence, the series of proposals requested and urged an end to the Negroes' second-class citizenship.

By 1835 many Negroes realized their ineffectiveness since they lacked political strength. Now they decided to use the press to pressure the politicians to giving them what they wanted. The Negroes lack of political power can be gleamed from an examination of two counties in New York City. In Kings County there were some 1,977 Negroes but only thirty-eight could vote. It was similar in Queens County where some $2,8 \mathrm{I}_{3}$ Negroes resided and only ten voted. ${ }^{4}$ In 1837, two years later, Negroes recognized their need for an alliance with other political groups in order to strengthen their political power. In that same year there were some 44,000 Negro residents in the State of New York but only a very small fraction of this number could vote. ${ }^{5}$

The new Negro strategy consisted of bombarding the politicians with petitions and currying public favor. Toward this end numerous Negro newspapers were established. Just to mention a few of the better known ones, we have: "The Liberator", "The New York Observer", "The Colored American", etc. There were many that never got off the ground.

Petitions were the favorite method employed by Negroes to alert the public to their plight by continuously mentioning them in the newspapers. On March 4, 1837, the Colored Citizens of New York State sent three petitions to Albany. One petition sought repeal of all laws authorizing out-of-state slave owners to bring their chattel (slaves) into the state for the permissible nine-month period. (It was

1 T. O. House, Anti-Slavery Activities of Negroes in New York, 1830-1860, (Master's Thesis, Howard University, 1936), p. 4.

${ }^{2}$ Address and Constitution of the Phoenix Society of New York (N.Y., I 833), p. 37.

${ }^{3}$ Minutes of the Fourth Annual Convention of the Free People of Color (N.Y., 1834), p. 13.

4 American Anti-Slavery Almanac (N.Y., I 843), Chronology, May.

5 Colored American, March I I, 1837. 
not until May I, I $84^{1}{ }^{1}$ that this was accomplished.) A second petition sought trial by jury for Negroes $;^{2}$ a third petition sought equal suffrage rights without regard to race, creed, or previous servitude. ${ }^{3}$ Again and again the petitions that were sent to Albany invariably met the same fate as the $182 \mathrm{I}$ Memorial - tabling or pigeon-holding. The lack of action effected by sending petitions caused some Negroes to become disgruntled and they decided to align themselves with interracial groups to bolster their cause. Thus, in 1837, many Negroes joined hands with members of the New York Anti-Slavery Society and drafted some thirty-nine resolutions relating to civil rights and liberties. ${ }^{4}$

Negro organizations in support of these demands were in abundance and never lacked in numbers. Both the abundance of organizations and members offered a reservoir from which Negro leadership sprang. In 1838 several new organizations were formed. One of these was the Political Improvement Association of New York City under the aegis of Charles L. Reason, an accomplished poet and journalist. This organization held its first meeting on October I I, I838. An executive committee was appointed and one of the committee's functions was to appoint ward committees. In turn, the ward committees were to distribute petitions for signature and when a sufficient number of names were collected these lists were to be sent to both local and national politicians. The objective was to force these politicians to note the strength of Negroes in combination with whites and to have the politicians introduce legislation to give the Negro equal citizenship with whites. The group held its second meeting on October 24, 1838, to evaluate its effectiveness as an organization in promoting the Negro's cause. ${ }^{5}$

Many young colored persons joined the ranks of their elders by forming their own organizations to push for equal suffrage. One such organization was the Political Association of New York City formed in 1838 . This organization started as an independent group, later it became affiliated with the Political Improvement Association of New York City. To help insure success throughout the state, similar youth organizations were established in most cities. The objective was first to gain public sentiment for the cause and than turn this sentiment into pressure on the politicians. ${ }^{6}$

1 Journal of the Assembly of New York State (Albany, r837), pp. 414-417.

2 The Emancipator, October 5, 1837.

3 The Colored American, October 20, 1838.

4 The Colored American, November I7, 1838 .

5 The Colored American, December I5, 1838 .

Ibid. 
Over and over again the Negroes' experience with politicians made them aware of their fragile position in the fight for equal suffrage. They recognized that the politicians would respond only to voting pressure and these bullets they lacked. Their predicament became more pronounced when they realized that the state's constitution specifically differentiated between white and colored suffrage requirements. To resolve this problem Negro leaders felt that only if Negroes increased their real property holdings to the minimum legal requirement could they hope to sway the politicians to give them equal suffrage. The three-year residence requirement was considered minor. Toward this end the editors of the "Colored American" agreed to underwrite the acquisition of real property. The editors pledged to supply up to one-half of the purchase price to anyone who would put up the other half in meeting the minimum legal requirement. ${ }^{1}$ But taxes were based on real property rather than on personal property and so many Negroes who had the cash thought better of it than to put their money into real estate. ${ }^{2}$

Even though the petition movement was frought with weaknesses, it continued to hold sway in the Negroes' efforts to gain equal suffrage. In addition to the petition movement, the direct approach was also utilized by some Negroes. The Colored Freeholders of the City and County of New York was one such group that favored direct political action. At a meeting held on October 29, 1838 , members of this group resolved to vote only for political candidates whose political platform would include elimination of "all distinctions in the constitutional rights of the Citizens of the State." 3 Toward this end, candidates of all parties in the 1840 election were interviewed. Support was given only to those candidates who agreed to plead the Negroes' cause. $^{4}$

Negro leaders, as individuals and in cooperation with organized groups, pushed the Negroes' interest in politics. These leaders emphasized over and over again the importance of the ballot as the means of eliminating the Negroes' "second-class citizenship". The names of a few Negro leaders rather active during the late I830's and throughout the 1840 's were: Charles Reason, Samuel Ward (a runaway slave), and Reverend H. Garnett. Previously, Mr. Reason was mentioned in connection with the Political Improvement Association of New York City; we did not mention that he often put into poetry the deplorable condition of the Negro. A few lines taken from "The

1 The Colored American, November 3, 1838.

2 The Colored American, November 17, 1838 .

${ }^{3}$ W. J. Simons, Men of Mark, Eminent, Progressive and Rising (Cleveland, I 887), p. I 110.

4 S. R. Ward, Autobiography of a Fugitive Negro (London, England, I855), p. 25. 
Spirit of Liberty Call to the Franchise" will illustrate the political aspirations of many Negroes.

"Come! rouse ye brothers, rouse nor let the voice

That shouting, calls you onward to rejoice,

Be heard in vain! but with ennobled souls,

Let all whom now an injust law controls,

Press on in strength to mind, in purpose bent

To live by right; to smell the free tones sent

A glorious promise for the captive's fate.

Then up! and vow no more to sleep, till freed

From partial bondage to a life indeed."1

Mr. Samuel R. Ward was a strong supporter of the Liberty Party, which stood for universal suffrage without regard to race, creed or previous condition of servitude. This political organization lasted about a decade, 1840-185 r. ${ }^{2}$ Reverend Henry Garnett, publisher of the "Clarion", 3 during the years $1839^{-1840}$, did much to apprise the Negro of the importance of the ballot.

\section{NEGROES STRESS THE BALLOT I $840-1850$}

The decade of the I 840's revealed the Negroes' increased stress on the importance of the ballot and their willingness to ally themselves with white "liberals". In 184I, the Freedmen's State Central Committee held one of its conventions and the reaction of the group was that a more consistent course of action was needed. This meant increased ballot power and the increased need for moral suasion amongst white "liberals". The convention closed on the note that each colored elector had a duty to perform - to vote on May II, I84r. ${ }^{4}$

A new act was passed on April 4, I842, affecting the colored man. This time each Negro elector had to swear that he was twenty-one years of age and that he had been a citizen of the State for one year and a resident of the county for four months prior to an election. In addition to the age requirement, the colored man had to possess $\$ 250.00$ in real property. If the colored man refused to take the oath, assuming that he owned $\$ 250.00$ in real property, he was automatically disqualified from voting. ${ }^{5}$

1 H. A. Garner, A Memorial Discourse, February I2, 1865 (Philadelphia, 1865), p. 33.

2 The Emancipator, May 6, I841.

${ }^{3}$ J. W. Edmonds, The Statutes at Large of the State of New York (Albany, I869), Vol. I, pp. 127-I 28.

${ }^{4}$ G. E. Baker (ed.), The Works of William H. Seward (N.Y., 1865), Vol. 3, pp. 237-238.

5 Ibid. 
In unison Negroes raised their voices to protest the new law. They rallied behind the Liberty Party which promised them relief. The Colored State Convention delegates backed the party to a man at its 1842 convention. Reverend Garnett addressed the convention and informed the group that the Liberty Party was their only salvation. There were powerful white political figures who also favored the Negroes' cause. One was William Seward, Governor of New York State from I 838-1842. Again and again, Seward addressed himself to the question of equal suffrage. On January 5, I843, Seward sent a letter to the Colored Citizens of New York thanking them for their previous support. ${ }^{1}$ On January 10, 1843 , he reiterated his feelings on the subject when he stated, "I should not deny them any right on account of the hue they wear, or of the land in which they or their ancestors were born." 2 In I 843 Garnett addressed the National Convention of Colored Citizens of Buffalo and urged them to give their unqualified support to the Liberty Party. ${ }^{3}$

Failure to achieve a goal usually gives rise to dissention; thus we find discontent manifesting itself within the Negro group in the middle of 1843 . One group of dissidents opposed the petitioning campaign and this group was spearheaded by the National Convention of Colored Citizens. Mr. Davis, a delegate to the convention, thought that more effective means were available to the Negro to push his cause. ${ }^{4}$ He stressed self-reliance rather than dependence upon white folk. Negroes should "seek a way to secure their own equal rights."5

Despite differences in strategy suggested, the flow of petitions remained the main source of protest employed by Negroes to obtain equal suffrage. A state-wide organization, the Fifth Annual Convention of Colored Citizens of the State of New York met on September I 8, 1844, in the City of Schenectady. This group reasserted their belief in the use of the petition as a major vehicle of change and set up a special agency to facilitate the presentation of appeals to the State Legislature. ${ }^{6}$

In 1845 , again some Negroes had misgivings as to the effectiveness of the petition program because political power and change is related to the number of votes a group can muster. 'The group's misgivings were based, partly, on the fact that only one thousand colored persons

1 Garner, op. cit., p. 44.

2 Minutes of the National Convention of Colored Citizens (Buffalo, August I5-19, 1843), p. 6.

3 Ibid., p. 7.

${ }^{4}$ Garner, op. cit., p. 43.

5 The New York State Convention, 1846 (Albany, 1846), p. 790.

6 The Liberator, May 23, 1845 . 
voted. ${ }^{1}$ One member of the opponents to the petition program, Wendell Philips, a white man, advocated revolution as the solution. He was chairman of the Business Committee's section of the AntiSlavery Society. This alternative was offered to the Anti-Slavery Society's members at a meeting held on May 6, I845, in New York City. ${ }^{2}$ Revolution was the only solution since there was "no hope of political regeneration, except in a revolution that would shake the very elements of society as they were in the fifteenth century, [a revolution that] would lay the political institutions of the land in ruins." 3 New political institutions, in turn, would pave the way for equal political and civil rights for all persons regardless of color, race, or previous condition of servitude.

Despite the Negro's standstill in the area of equal suffrage, radical solutions failed to sway him from his peaceful activities in seeking equal suffrage. Constant pressure on the politicians began to show some success in 1845 . In that year the state legislature did present to the voters a special act for referendum - the abolition of special voting qualifications for the Negro. The voters rejected the proposed amendment. ${ }^{4}$

Previously, continuous rejection of the Negro by whites in the area of civil rights forced the Negro to hold out little hope for change when New York State held its i 846 constitutional convention. As at previous conventions, some equal suffrage advocates were present. One advocate of equal suffrage, Andrew Young, ${ }^{5}$ offered a resolution that special property qualifications be abolished. Immediately after his presentation, the Committee on Elective Franchise modified the resolution by dividing it into two sections. Section one offered every white qualified citizen the right to vote for all officers of the state. Section two offered the same privileges to the Negro. Each section was to be voted upon separately. Past experience repeated itself; the Negro continued to have unequal suffrage.

Most of the equality arguments enunciated at the 1846 Convention were repeats of those voiced at the 182 I Convention. Once more it was suggested that the word white be deleted from the first section of the law and made applicable to all citizens regardless of color. ${ }^{6}$ Other equal righters requested that the convention delegates re-

1 Ibid.

2 The Liberator, July 4, 1845 .

${ }^{3}$ Report and the Debates and Proceedings in the New York State Convention for Revision of the Constitution, 1846 (Albany, 1846), p. 790.

Ibid., p. 775 .

5 Ibid., p. 776.

Ibid., p. 777 . 
establish the voting requirements for blacks as was originally found in the 1777 Constitution. ${ }^{1}$

Like their counterparts, opponents to the extension of equal suffrage reiterated the same objections heard at previous conventions. The anti-Negro suffrage group alleged that: I) "the Negro was created inferior", and 2) "that the history of the world has shown him [the Negro] incapable of free government." 2 The debate commenced on June I 3,1845 , and continued through October I, I846, with a short recess during this period. When it came to a vote, it was decided that two seperate sections would be presented to the voters; $\sigma_{3}$ were for two sections and 37 for one section. ${ }^{3}$

Accustomed to failure, proponents of equal suffrage rights refused to admit defeat. This time they sought to modify the real property qualification by reducing the $\$ 250.00$ figure to $\$ 100.00$. Once more white liberals suffered a set-back but managed to convince some of the delegates to switch their vote. This time the vote was 50 to 42 , a much narrower margin than on the previous issue.

Finally, the equal suffrage amendment was placed before the voters on October 9, I 846.4 Subordinate Negro rights were again upheld by the voters when 224,336 voted against liberalization of Negro suffrage ${ }^{5}$ and 85,406 voted in favor of the amendment. ${ }^{6}$

Defeat meant renewal of efforts to increase the Negroes' political power. This was synonymous with increasing the number of colored landowners. A white liberal, Gerrit Smith, donated a huge tract of land to be distributed amongst Negroes in an effort to increase the number of eligible Negro voters. ${ }^{7}$ Negro leaders, like Ward ${ }^{8}$ and Garnett, kept both the colored and white public sensitive to the issue both during and after the I 846 election. In 1847 Garnett summoned the National Convention of Colored People to Troy, New York. At Garnett's behest the delegates to the convention adopted a resolution stressing the growing impatience of Negroes with their "second-class citizenship". Also, it was agreed upon during this meeting that more conventions should be held and that more newspaper articles would sensitize the public to the Negroes' cause. ${ }^{9}$

1 Ibid., p. 788 .

2 Ibid., p. 790.

3 Ibid., p. 828 .

4 Ibid., p. 836 .

5 Tribune Almanac for 1870, p. 53.

- Garnett, op. cit., p. 53.

7 Ward, op. cit., p. 77.

${ }^{8}$ Proceedings of the National Convention of Colored People Held at Troy, New York (Troy, 1847), October 6-9, 1847, p. 17.

Ibid. 
The next decade and a half, I850-1865, saw the organized colored movement stress greater need for direct political action. Again, an old panacea was raised - colonization. Also, during this period, there was definitely a favorable change in attitude toward the suffrage issue by politicians.

In 18 I 1 the colored residents of New York City called another mass meeting to advance their cause. At this meeting, it was resolved that: I) when voting Negroes should consider the political parties' previous action toward their welfare and 2) when considering new schemes, they should be submitted to the special committee for clearing. ${ }^{1}$

Another theme discussed at this meeting was introduced by Mr. Simons. He, an influential member of New York City's colored society, like Mr. Davis back in the 1840's, revived the idea that Negroes should develop their own group's resources. Self-reliance was the note on which the first meeting ended. ${ }^{2}$

A second meeting was held on October $3,1851 .^{3}$ At this meeting, the chairman distilled the special committee's recommendations recommendations previously submitted to the committee for clearance. The major theme that emerged was emigration to a foreign land. A country in Africa was to be chosen, then an agent was to be sent to make the necessary arrangements. These arrangements were to include the guarantee of equal socio-economic and political status with that of the indigenous population of that country. ${ }^{4}$ (No mention was made of the previous colony set up by the Colonization Society in Liberia.)

If emigration to a foreign land meant self-reliance, this was not what Simons had in mind. This meant defeat. After the chairman had completed his report, Simons took the floor and reviewed the emigration question as it had developed over the past twenty-five years. $\mathrm{He}$ pointed out its failure to lure Negroes abroad. Also, he made the point that the failure of emigration to take hold indicated that Negroes preferred life in the United States. Still many Negroes continued to embrace the idea of emigration. For example, Van Dyne who followed Simons to the platform introduced several resolutions consistently related to emigration. With respect to the unequal

1 The New York Herald, September 6, I847, p. I7.

2 Ibid.

8 The New York Herald, October 3, I85 I.

4 Ibid. 
treatment of Negroes, Van Dyne' resolved that: "We, the free colored people of the City of New York... have, for a series of years, suffered from unjust and cruel prejudice and degradation to which they have consigned us;... we do, after due consideration, deem it indispensibly necessary to our future well-being, that some immediate and decisive action on our part be suggested and wisely entered into." His second resolution made obvious the direction Van Dyne was heading - emigration, since he called for the organization and propagation of a group to be called "United African Republic Emigration Society". ${ }^{2}$ Logically, such an organization had to be implemented to fulfill its purpose. The third resolution included the necessary functions to activate the new society.

In other parts of the state other Negroes were leaning in the same direction - emigration. On July 6, 1853, the National Colored Convention met at Rochester, New York and the convention delegates were addressed by Frederick Douglass. His address was pointed toward the question of foreign colonization. Like Simons, Douglass implied that emigration was no solution to the problem of unequal suffrage. "We ask that an unrestricted right to suffrage, which is essential to the dignity of the white man be extended to the free colored man also."3

On January $x_{3}, 1857$, the State Senate reopened the question of the special property qualifications required of Negroes to vote. One of the Senate's resolutions dealt with the deletion of the word white from Article two of the Constitution. The law required that any such proposed change must be published at least three months prior to the next election. ${ }^{4}$ Both the Assembly and the Senate passed the resolution. ${ }^{5}$ However, the resolution was not published within the required three-month period previous to the next election. This made it technically impossible for the voters to act upon it. One explanation offered for this oversight was given by Governor John A. King in his annual message to the legislature: "In the hurry of business, the amendment to the Constitution relating to Negro suffrage was inadvertently sent to the Executive Chamber, among other bills... [it was] laid aside." Governor King suggested that the legislature re-enact this amendment. ${ }^{6}$

1 Ibid.

2 Ibid.

3 Proceedings of the Colored National Convention (Rochester, N.Y., 1853), July 6-8, I 853, P. 9 .

4 Journal of the Senate, 1857 (Albany, I 857 ), p. 67.

5 Ibid., p. 354 .

6 Documents of the Assembly of the State of New York, I857 (Albany, 1857), pp. I I-1 2. 
By the end of the I 850 's equal suffrage for Negroes became a perennial issue. In I859, the Honorable Charles S. Spencer of the City of New York argued in the legislature that "neither the color of one's skin nor African descent should be a basis for unequal citizenship." The State Assembly adopted a resolution abolishing the special property qualifications required of Negroes to vote. This resolution likewise required that it be published three months prior to an election. ${ }^{2} \mathrm{~A}$ rider to the bill would extend suffrage to all females by deleting the word "male" from the election laws."

In May I 860 the Free Suffrage Convention held its meeting in New York City, an indication of the Negroes' sustained interest in the suffrage question. The convention chairman made public two resolutions formerly adopted by the group. The first stated that the Colored People of the State based their claim to the elective franchise on the principles of human freedom and equality as set forth in the Declaration of Independence. ${ }^{4}$ The second resolution proclaimed that, "as descendants of the revolutionary dead, as citizens of the Empire State, as citizens of the United States, we appeal to every voter in the State to give us practical recognition of the principle upon which this government professes to be based, by noting at the November election to strike out from the State's Constitution that anti-Republican qualification clause which now disgraces it."5

On April 10, 1860, again an act was read to perfect an amendment to the State's Constitution; an act to abolish the property qualifications in force against Negroes. This time the amendment was unanimously adopted and then referred to the Judiciary Committee for final drafting. ${ }^{6}$ On April I 3, I 860, both houses approved the bill; $;^{7}$ the amendment was defeated by a majority of 140,$429 ;^{8}$ the relative decrease in the majority since the 1846 election was a form of victory for the Negro.

Rejection by the voters did not deter the Negroes from pressing the issue during the decade of the I860's. February 27, I86I, saw the Negroes presenting a new petition to the State Assembly and yet another on January 6,1864 , demanding equal suffrage. ${ }^{9}$

${ }^{1}$ An Appeal for Freedom, Made in the Assembly of the State of New York, March 7 , I859, by the Honorable Charles S. Spencer, p. 9.

2 Journal of the Assembly of New York State, 1859 (Albany, 1859 ), pp. 730-732.

3 Ibid., pp. 64, 203, 532, 606, and 730 .

4. W. Nell, Property Qualifications or no Property Qualifications (N.Y., 1860), p. 3. 5 Ibid.

6 Journal of the Assembly of the State of New York, I860 (Albany, I860), p. I129. 7 Ibid.

${ }^{8}$ C. Z. Lincoln, Constitutional History of New York (Rochester, N.Y., 1906), Vol. 3, pp. 232-233.

$\checkmark$ Journal of the Assembly, I 864 (Albany, I 864), p. 32. 
Negroes recognized that the legislature was only an initiating body and they had convinced this august body of the righteousness of their cause; hence why could not they do the same with the voters?

So while the State Legislature was discussing the issue Negroes now concentrated on persuading the voters of the validity of their cause. One group of Negroes headed by Sprague and Wilkerson with some one thousand helpers were out gathering signatures on January 23, I 865. These petitions were then turned over to the State Assembly requesting another public confrontation on the issue. ${ }^{1}$ Reverend Garnett continued to keep the issue alive before the public. He made a rather impressive and impassioned speech before the National Convention of Colored Men on October 4, 1865, at Syracuse, New York. Despite Negro activity and the assistance of certain white groups, the public failed to grant equal suffrage to the Negro until the Fifteenth Amendment to the Federal Constitution was passed in 1870 .

\section{SUMMARY}

Despite the institutionalization of black subjugation starting in colonial times, New York State's first Constitution, adopted on April 20, I777, made no reference to race, creed or previous condition of servitude as a basis for suffrage. However, by 1809 Negro suffrage was well within the orbit of inferior status, a status in accord with the social and economic institutions restricting the Negro's equal opportunity in society. Restrictions became more stringent after the Negro was freed by an act of the State Legislature in 1827. Abolition of slavery saw the beginnings of Negro reaction to wipe out the institutionalization of subjugation. To attain his ends the Negro, on the political front, continuously petitioned the State Legislature to right a wrong. Passage of the years saw the Negro win over the politicians but not the public before passage of the Fifteenth Amendment. It was heartening to the Negro to note that the legislature could be prevailed upon to present an amendment to the public even though it was constantly defeated by the voters. On the other hand the willingness of the politicians to present the amendment over and over again to the public may have been predicated on the fact that the public would reject it. This would be one way in which the legislators could shift the wrath of the Negroes from them to the public.

These set-backs failed to deter the Negro from pressing the issue, and such radical solutions as revolution, emigration, etc., never invaded the grass roots of the Negro population. Passage of the Fifteenth Amendment to the Federal Constitution saw the Negro attain, at least nominally, equal suffrage rights in New York State.

1 Journal of the Assembly, 1865 (Albany, I865), p. I29. 